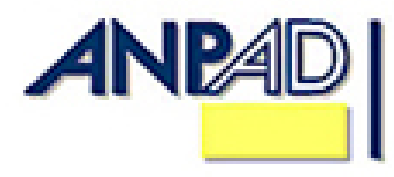

\author{
Available online at \\ http://www.anpad.org.br/bar \\ BAR, Rio de Janeiro, v. 11, n. 3, art. 6, \\ pp. 340-363, July/Sept. 2014 \\ http://dx.doi.org/10.1590/1807-7692bar2014309

\title{
A Bibliometric Study on Culture Research in International Business
}

Claudia Frias Pinto

E-mail address: claudia.frias.pinto@gmail.com ESTG - Instituto Politécnico de Leiria; UNINOVE - Universidade Nove de Julho Uninove, Av. Francisco Matarazzo, 612, Prédio C - 2º , 05001-100, São Paulo, SP, Brazil.

Fernando Ribeiro Serra E-mail address: fernandoars@uninove.br UNINOVE - Universidade Nove de Julho Uninove, Av. Francisco Matarazzo, 612, Prédio C - 2º , 05001-100, São Paulo, SP, Brazil.

Manuel Portugal Ferreira E-mail address: manuel.portugal@uninove.br UNINOVE - Universidade Nove de Julho Uninove, Av. Francisco Matarazzo, 612, Prédio C - 2º , 05001-100, São Paulo, SP, Brazil.

Received 16 February 2013; received in revised form 6 February 2014 (this paper has been with the authors for two revisions); accepted 14 February 2014; published online $1^{\text {st }}$ July 2014. 


\begin{abstract}
National cultures and cultural differences provide a crucial component of the international business (IB) research context. We conducted a bibliometric study of articles published in seven leading IB journals over a period of three decades to analyze how national culture has been impacting IB research. Co-citation mappings permit us to identify the ties binding works dealing with culture and cultural issues in IB. We identify two main clusters of research, each comprising two sub-clusters, with Hofstede's (1980) work delineating much of the conceptual and empirical approach to culture-related studies. One main cluster entails works on the conceptualization of culture and its dimensions and the other cluster focuses on cultural distance. This conceptual framework captures the extant IB research incorporating culture-related concepts and influences.
\end{abstract}

Key words: culture; culture in international business; bibliometric study; IB research. 


\section{Introduction}

International business (IB) research seeks to understand firms' internationalization decisions. These decisions comprise location choices, foreign-entry modes, international strategies, organizational formats, international human-resource practices, among others. In fact, the domain of IB as a field of study is distinguishable from management of domestic large corporations because multinationals operate in a more complex international business environment than purely domestic firms. In fact, Ferreira, Li, Guisinger and Serra (2009) stated that IB is focused on understanding the environmental context in which firms operate. According to Boyacigiller and Adler (1997) "by definition, international business is contextual. International Business includes, specifically, the external international environment, in which firms conduct their businesses" (p. 398).

Culture is a core environmental dimension in IB studies. Ferreira et al.'s (2009) study of articles published in the Journal of International Business Studies over a span of thirty years noted that culture was the most often used environmental dimension. Tung and Verbeke (2010) argued that a measure cross-cultural research's impact is provided in the evidence that there were more than 54,000 citations of Hofstede's work as of June 2010. In fact, especially since the 1980s, several scholars started including national culture in their research, mostly using Hofstede's (1980) taxonomy.

Culture's importance is well established in the discipline but in this article we advance on existing studies to better understand the main streams of IB research that have incorporated culture and its ties to different phenomena and theories. Our methodological approach - based on a bibliometric study of 502 articles published in the top seven journals for IB research - permits deeper analyses than traditional literature reviews (Kirkman, Lowe, \& Gibson, 2006; Leung, Baghat, Buchan, Erez, \& Gibson, 2005; Minkov \& Hofstede, 2011) and insights into past trends and evolution of the literature (Ferreira, 2011; Ramos-Rodríguez \& Ruíz-Navarro, 2004).

In this study we gain a better understanding of the nature and evolution of extant IB culturerelated research. The results point to noteworthy findings. First, and perhaps not surprising, is the central role of Hofstede's work on culture in IB studies, although there are alternative cultural taxonomies developed during the last two decades (see Taras, Rowney, \& Steel, 2009, for a review). Second, we discovered that much of IB research dedicates attention to cultural distance, and not merely absolute dimensions of national culture. Third, we identified a substantial cluster of works pertaining to the conceptualization of culture and its components, and another cluster comprising works on cultural distance, both conceptual and applied to other IB phenomena. We also identify the importance of institutional and transaction cost arguments in these clusters.

This paper complements prior reviews, meta-analyses and bibliometric studies. For instance, some scholars have delved into examining the impact of Hofstede's (1980) research, how it has been incorporated (Kirkman et al., 2006), how Hofstede's doctrine has evolved over time (Minkov \& Hofstede, 2011), and how Hofstede's work compares and contrasts alternative conceptualizations (Brewer \& Venaik, 2011; House, Hanges, Javidan, Dorfman, \& Gupta, 2004; Javidan, House, Dorfman, Hanges, \& Luque, 2006). Occasionally, this has meant examining the impact of specific cultural dimensions, such as individualism-collectivism (Earley \& Gibson, 1998; Oyserman, Coon, \& Kemmelmeier, 2002; Triandis, 1995, 2004), that permitted only narrow implications and conclusions, or expanding to other cultural models (Brewer \& Venaik, 2011). Or, as in Shenkar $(2001,2012)$ discussing how to better the conceptualization and measurement of cultural differences, and Taras, Rowney, and Steel's (2009) review of the extant instruments and measurements of culture. Other studies have either reviewed the entire IB discipline (Acedo \& Casillas, 2005; Werner, 2002), noted the evolution and trends in intercultural research (Adler, 1983), or ignored the specific phenomena to which culture was applied, emphasizing only the cultural aspects and comparisons among cultures (Smith, Peterson, \& Schwart, 2002). Yet others have examined culture in IB, such as Leung, Baghat, Buchan, Erez, and Gibson's (2005) conceptual piece on cultural convergence and divergence and proposals for future research, without assessing how it has been used. Hence, an analysis of even 
recent works reveals little overlap between our study and other extant research, and our study adds value beyond previous reviews and related works, as we not only identify how culture has been integrated in IB studies, but we are also able to gain an integrative understanding involving culture. Moreover, at least to some extent, we overcome analysis that provides a fragmented perspective of Hofstede-inspired research.

This paper is organized in four sections. First, we briefly review what culture is, its dimensions or components, and its connections with international business. Second, we present the methods, including the procedures and sample. The third section includes the results. We then discuss the results and present limitations and future research avenues.

\section{Literature Review}

"The business of International Business is culture" (Hofstede, 1994, p. 1). Following Hofstede (1991), culture is "the collective programming of the mind which distinguishes the members of one group from another" (p. 21). Tihanyi, Griffith, and Russell (2005) defined culture as "the homogeneity of characteristics that separates one human group from another" (p. 271). Wit and Meyer (1998) noted national culture as a shared set of values, norms, beliefs and expectations. Hence, studying national cultures provides a profile of the characteristics of a society concerning norms, values and institutions, thus allowing for a better understanding of how societies manage interactions (Hofstede, 1980; Trompenaars, 1993). A different view on culture and its idiosyncrasies is put forth in Meyer, Boli, Thomas, and Ramirez (1997) arguing that, at least in many instances, there is a worldwide culture developing and cultures are not as isolated as Hofstede, and other scholars, espouse. In this vein, there are some isomorphic processes and pressures that may render a far more universalistic sharing of some values, norms and behaviors.

For multinational corporations (MNCs) with dispersed operations, understanding cultural differences and how they influence firms' operations is crucial. Thus, it is not surprising that national culture has a long tradition in IB research (Kirkman et al., 2006). Culture and cultural differences seem to permeate a broad set of firms' decisions and practices in IB, such as entry-mode selection (Kogut \& Singh, 1988; Morosini, Shane, \& Singh, 1998), location (Erramilli, Agarwal, \& Kim, 1997), MNC management and performance (Gómes-Mejia \& Palich, 1997), joint-venture performance (Pothukuchi, Damanpou, Choi, Chen, \& Park, 2002), knowledge transfer between subsidiaries (Sarala \& Vaara, 2010), governance (Kang \& Kim, 2010), and ethics (Ralston et al., 2009), among others.

Thus, understanding the nature and influence of national culture and how cultures differ is central to IB research (Ferreira, Li, Guisinger, \& Serra, 2009). In a literature review, Griffith, Cavusgil, and $\mathrm{Xu}$ (2008) identified culture, conflicts and cognition - including the influence of national culture in research into strategic management and firms - among the eight themes researched the most in IB studies. For firms, there are substantial potential hazards and additional managerial and transactional costs of interacting and operating in unknown foreign environments (Anderson \& Gatignon, 1986; Zaheer, 1995). These may entail, for instance, the transactional difficulties in sharing knowledge across borders (Kogut \& Zander, 1993) and the choice of which entry modes to adopt (Shenkar, 2001).

\section{Cultural taxonomies}

One of the most notable contributions to understanding what a culture entails and to including culture in conceptual and empirical IB research was that of Geert Hofstede. In his 1980 book on Culture's consequences: International differences in work-related values, Hofstede proposed that we examine four cultural dimensions to characterize a country. In later works, Hofstede and Bond (1988) added a fifth dimension - Confucian dynamism - and in 2010, a sixth dimension - indulgence $v s$. retention. 
Other scholars have studied national cultures and advanced alternative, albeit often complementary, taxonomies that help explaining cultural differences between peoples and countries. Edward Hall (1976) stood out for his emphasis on communication differences between cultures. Schwartz (1994) identified seven cultural dimensions of values that included conservatism, intellectual autonomy, affective autonomy, hierarchy, egalitarian commitment, harmony and mastery. Trompenaars and Hampden-Turner (1998) work Riding the waves of culture presented a set of seven cultural dimensions. These referred to relationships with other people, attitude towards time (past, present and future) and attitudes towards the environment. More recently, House, Hanges, Javidan, Dorfman, and Gupta (2004) and Gupta and House (2004) described the GLOBE project - Global Leadership and Organizational Behaviour Effectiveness, aiming to "describe, understand and predict the impact of specific cultural variables in leadership and organizational processes" (House et al., 1999, p. 492).

Some cultural research has been used to guide the theory and practice of management in IB (Scholtens \& Dam, 2007; Tihanyi, Griffith, \& Russell, 2005) and especially research. Rubera, Ordanini, and Griffith (2011) used Schwartz's cultural dimensions to empirically investigating the influence of cultural values on the relationship between creativity dimensions and intention to buy. Fischer and Mansell (2009) examined the effects of individualism-collectivism and power-distance values and practices (Hofstede's and GLOBE's) on commitment levels. Sarala and Vaara (2010) used GLOBE's cultural dimensions to examine how national cultural differences affect knowledge transfer. Berry, Guillén, and Zhou (2010) proposed a new approach to conceptualizing, measuring and examining the influence of cross-national distance. Taras et al. (2009) examined 121 instruments utilized in the quantitative measurement of cultural values developed over the last half a century to reveal how culture has been operationalized.

\section{Cultural distance}

Few constructs have been so well accepted in IB literature as cultural distance (Shenkar, 2001, 2012). Cultural distance may be defined as the degree of difference between two countries' cultural norms (Kogut \& Singh, 1988), including social norms, religions, languages and ethnicities (Shenkar, 2001) that distinguish one country from others. Hennart and Larimo (1998) defined cultural distance as "the national cultural characteristics of the home and of the host countries" (p. 517). Berry et al. (2010), using institutional theory, conceptualized cultural distance as "the differences in attitudes toward authority, trust, individuality and importance of work and family" (p. 1464).

Related to the static cultural traits emphasized in the cultural taxonomies, a stream of research has specifically dealt with cultural differences and how these affect an array of IB decisions. For instance, entry-mode selection (Brouthers \& Brouthers, 2001; Erramilli \& Rao, 1993; Hennart \& Larimo, 1998), M\&A performance (Chakrabarti, Gupta-Mukherjee, \& Jayaraman, 2009; Morosini et al., 1998), and international diversification (Tihanyi et al., 2005). This research used cultural distance to understand not only national cultures per se, but also how they differ and how these differences impact firms' choices and strategies (Kogut \& Singh, 1988).

Research using cultural distance descends from a line of study that introduced the concept of psychic distance (Dow \& Karunaratna, 2006; Johanson \& Vahlne, 1977, 1990; Johanson \& Wiedersheim-Paul, 1975) often to study foreign-entry modes and market selection. Psychic distance is somewhat broader than cultural distance and encompasses inter-country differences in economic development, income profiles and geographic distances. Johanson and Wiedersheim-Paul (1975) defined psychic distance as those "factors that prevent or disturb the flows of information between firms and markets" (p. 308). Notwithstanding, cultural differences among countries are the most recognized form of psychic distance (Dow \& Karunaratna, 2006). 


\section{Method}

Bibliometric studies use a set of mathematical and statistical methods to quantitatively analyze scientific literature (Bellis, 2009; Cronin, 2001). Bibliometric studies aim to detect intellectual networks binding scholars to make some sense of and organize the extant literature (Pilkington \& Meredith, 2009), assess trends on a given subject or discipline, identify main theories and more productive scholars or institutions, or identify and map the intellectual structure of a discipline or area of study (Acedo, Barroso, \& Galan, 2006; Guarido, Machado-da-Silva, \& Gonçalves, 2009; Guarido, Machado-da-Silva, \& Rossoni, 2010; Pilkington \& Meredith, 2009; Ramos-Rodríguez \& RuízNavarro, 2004).

Bibliometric studies have been used to examine an array of different objects in International Business. For instance, Ferreira (2011) examined the contribution and impact of a specific scholar, Sumantra Ghoshal, on the study of MNCs. Treviño, Mixon, Funk and Inkpen (2010) observed the authors and institutions with the greatest contribution to the evolution of the IB discipline. Inkpen and Beamish (1994) examined one journal - Journal of International Business Studies (JIBS) - over a twenty-five year period to verify main developments, and Werner (2002) focused on trends in IB literature. Chandy and Williams (1994) used the articles published in JIBS to observe the influence some authors and disciplines have in IB research. Chandy and Gopalakrishna (1992) made a content analysis of contributions found in the Management International Review (MIR).

\section{Procedures}

Data collection was based on bibliometric techniques, because these are especially useful when analyzing large volumes of information where it is not viable to use usual content-analysis procedures. The sample of articles used was drawn from seven highly reputed journals for IB research. Albeit there are several possible sources of data, published articles are especially relevant, since these have undergone a peer review process and are considered certified knowledge. The data was collected from ISI Web of Science. This source has been used by multiple scholars (e.g., Cronin, 2001; Harzing \& Wal, 2009; Peng \& Zhou, 2006) and is among the most complete, including documents going as far back as 1900 from over 12,000 journals (Thomson Reuters, 2014).

We drew the data from the top seven journals for IB research (Table 1). The journals were identified using DuBois and Reeb (2000), Treviño et al. (2010), Anne-Will Harzing's (2014) Journal quality list, and the journals' respective impact factors. Moreover these journals, or a subsample, have been used in previous studies (e.g., Peng \& Zhou, 2006). It is worth noting that in 1997, Columbia Journal of World Business (CJWB) was renamed as Journal of World Business (JWB). Table 1 includes some descriptive elements of these journals, such as the number of articles published, impact factors, number of total citations to the articles published and the position in three different rankings. Albeit the time frame for this study is rather long, initiated in 1965, the founding year of CJWB, not all journals have their entire record available in ISI Web of Knowledge. For instance, MIR editions are available only for the years between 1966-1990 and 2008-2012. JIBS, on the contrary, has been fully available since 1976. 
Table 1

The Selected Journals

\begin{tabular}{|c|c|c|c|c|c|}
\hline Journals & $\begin{array}{c}\text { Years } \\
\text { available in } \\
\text { ISI }\end{array}$ & $\begin{array}{l}\text { N. of articles } \\
\text { published }\end{array}$ & $\begin{array}{l}\text { N. of citations } \\
\text { to the articles } \\
\text { published }\end{array}$ & $\begin{array}{l}\text { Impact } \\
\text { factor }\end{array}$ & h-index \\
\hline $\begin{array}{l}\text { Journal of International Business Studies } \\
\text { (JIBS) }\end{array}$ & $1976-2012$ & 1,287 & 45,124 & 3.406 & 101 \\
\hline Journal of World Business (JWB) & $1997-2012$ & 487 & 6,339 & 2.383 & 37 \\
\hline International Business Review (IBR) & $2005-2012$ & 347 & 2,094 & 1.511 & 22 \\
\hline $\begin{array}{l}\text { Management International Review } \\
\text { (MIR) }\end{array}$ & $\begin{array}{c}1966 \text { to } 1990 \\
\text { and } \\
2008-2012\end{array}$ & 952 & 2,481 & 0.754 & 21 \\
\hline $\begin{array}{l}\text { Journal of International Management } \\
\text { (JIM) }\end{array}$ & $2007-2012$ & 147 & 674 & 1.698 & 12 \\
\hline $\begin{array}{l}\text { European Journal of International } \\
\text { Management (EJIM) }\end{array}$ & $2008-2012$ & 137 & 120 & 0.474 & 4 \\
\hline $\begin{array}{l}\text { Columbia Journal of World Business } \\
\text { (CJWB) }\end{array}$ & $1965-1996$ & 1,443 & 3,758 & - & 23 \\
\hline Total & & 3,220 & 56,712 & & \\
\hline
\end{tabular}

Note. Sources: rankings from Harzing, A-W. (2014, February 11). Journal Quality List (52th ed.). Australia. Retrieved from http://www.harzing.com/download/jql_journal.pdf. Data on dates of publication, number of articles and impact factors were drawn from Web of Science. (n.d.). Pesquisa básica. Retrieved from http://apps.webofknowledge.com/WOS_GeneralSearch_input.do?product=WOS\&SID=Q2VSsC8ChkihDbZkvFR\&search_ mode $=$ GeneralSearch

The sample was identified with ISI Web of Knowledge using the following procedure. First, we selected only these seven journals, and second, in the option topic we searched for the key words: culture, national culture, cultural distance and their variations. The search was conducted for title, abstract, and author-supplied keywords. We excluded book reviews, editor notes and other documents from the sample. Moreover, the initial listing of 679 articles was screened to assure that the articles were on national culture rather than, for instance, on organizational culture (Ito, Fujimura, \& Tamiya, 2012) and organizational values (Michailova \& Minbaeva, 2012), or any other context. The final sample comprised 502 articles.

After the data were gathered and coded with the software Bibexcel, we used frequency counts to identify the most highly-cited articles (see Table 2). Next, we developed a co-citation matrix, and standardized the co-citation data for further analysis. This matrix, that assesses proximity between pairs of works, comprises the references both in rows and columns, with the frequency of cooccurrence in each cell of the matrix. Subsequently, we used metric multidimensional scaling (MDS). MDS pictures the structure of a set of objects from data that approximate the distances between object pairs (Young, 1985), and may be displayed in a visual representation (see Figures 2 and 3). This required that we increase the number of articles included in the analysis until we reached the threshold for a good model fit. Following common practice in bibliometrics, we used a stress value of 0.10 or below as the basis for good model fit (Ramos-Rodríguez \& Ruíz-Navarro, 2004). The stress value indicates how well the data fit a particular configuration, such that the higher the stress, the poorer the fit (Robinson \& Bennett, 1995). That is, adding more articles to the co-citation matrix increases the stress value, making the ensuing configuration more ambiguous. Hence, we constructed two figures, one with 16 articles and the other with 37 articles, for analysis. In the visual display (Figures 2 and 3) the proximity between works is a measure of the strength of the tie and the size of the circles is a function of the citations to each specific work. 


\section{Sample}

The final sample comprises 502 articles, distributed among the journals: JIBS (221), MIR (47), JWB and CJWB (105), IBR (71), JIM (26) and EJIM (32). JIBS contributed the largest number of articles to our sample. The 502 articles, out of a total of 3,220 articles published in these journals, account for $15.6 \%$ of the total published in these journals - which also denotes the relevance of culture in IB research. Moreover, albeit our sample comprises articles published in only seven IB journals, these are the journals with the highest impact factors and are specialized in IB.

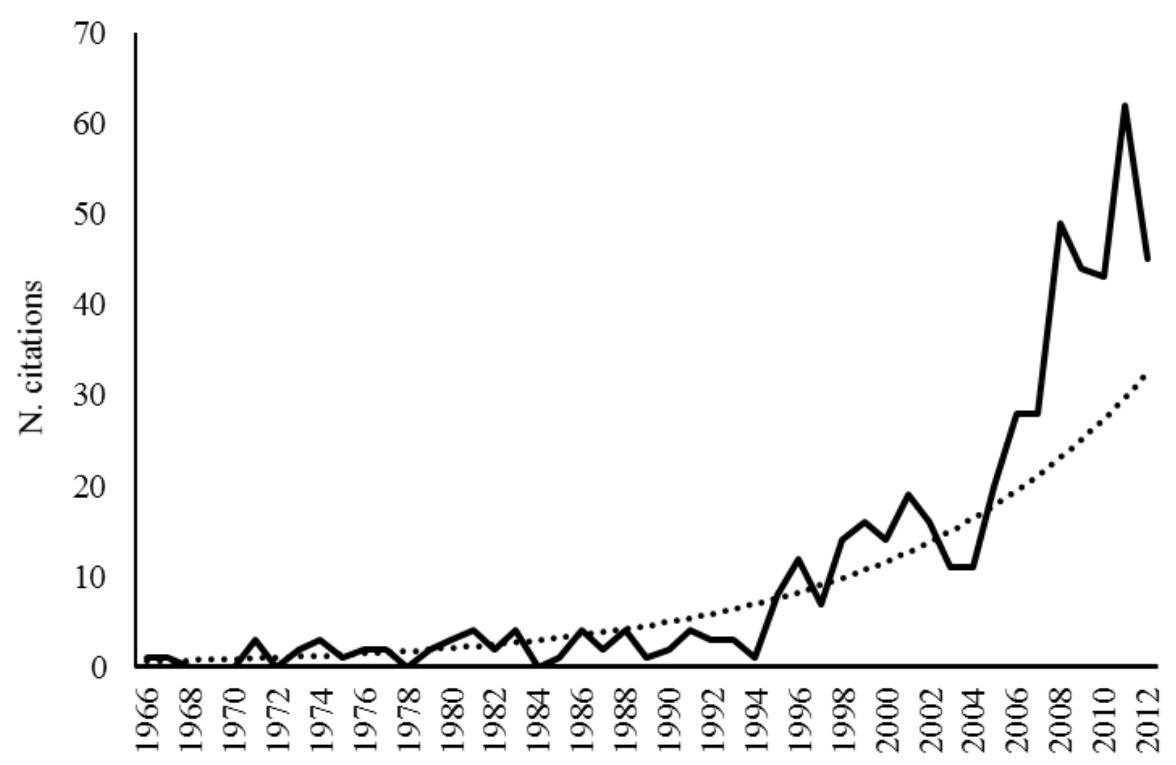

Figure 1. Citations Frequency.

Figure 1 reveals the citation frequency over the period. It denotes a broadly ascending trend in citations with an exponential function, revealing the increasing number of citations. Nonetheless we may identify two periods, one up to 1994 with a reasonably low number of counts, and the other from 1995 onwards with a marked increase in citations count. This trend evidences the escalation in culturerelated IB research in the past two decades.

\section{Results}

The 502 articles of our sample used a total of 56,712 references (Table 1). In Table 2 we observe the top 37 most cited works - referenced in 1,630 works. Hofstede's (1980) work has the largest number of citations, followed by Kogut and Singh (1988) on cultural distance, House et al. (2004) on the GLOBE project and Shenkar's (2001) discussion on cultural distance. We also show the articles in each of the clusters we identify below (Figures 2 and 3) with the relative percentages of citations to each paper within its cluster. For instance, Hofstede's (1980) book was the most-cited work (cited by $69.3 \%$ of all papers) and also the relatively most cited in its cluster (47\%). In subcluster \#1.2, the most cited work was Hofstede and Bond (1988) (17\%), while Kogut and Singh's (1988) work was cited by $27 \%$ of the works in subcluster 2.1 . These three works denote three different emphasis: conceptualization of culture, extensions on the cultural taxonomies and complexity, and the more recent concept of cultural distance. 


\section{Table 2}

Most Cited Works

\begin{tabular}{|c|c|c|c|c|c|c|}
\hline $\mathrm{N}$ of citations & Reference & $\%$ & $\begin{array}{c}\text { Cluster } \\
1.1\end{array}$ & $\begin{array}{c}\text { Cluster } \\
1.2\end{array}$ & $\begin{array}{c}\text { Cluster } \\
2.1\end{array}$ & $\begin{array}{c}\text { Cluster } \\
2.2\end{array}$ \\
\hline 348 & Hofstede (1980) & 69.3 & $47 \%$ & & & \\
\hline 134 & Kogut and Singh (1988) & 26.7 & & & $27 \%$ & \\
\hline 79 & House et al. (2004) & 15.7 & $11 \%$ & & & \\
\hline 79 & Shenkar (2001) & 15.7 & & & $16 \%$ & \\
\hline 49 & Johanson and Vahlne (1977) & 9.8 & & & $10 \%$ & \\
\hline 47 & Morosini, Shane and Singh (1998) & 9.4 & & & $9 \%$ & \\
\hline 45 & Ronen and Shenkar (1985) & 8.9 & $6 \%$ & & & \\
\hline 45 & Hofstede and Hofstede (1991) & 8.9 & $6 \%$ & & & \\
\hline 42 & Barkema, Bell and Pening (1996) & 8.4 & & & $8 \%$ & \\
\hline 37 & Gatignon and Anderson (1988) & 7.4 & & & $7 \%$ & \\
\hline 36 & Triandis (1995) & 7.2 & $5 \%$ & & & \\
\hline 36 & Schwartz (1994) & 7.2 & $5 \%$ & & & \\
\hline 35 & Hofstede and Bond (1988) & 6.9 & & $17 \%$ & & \\
\hline 31 & Kirkman, Lowe and Gibson (2006) & 6.2 & $4 \%$ & & & \\
\hline 30 & Kim and Hwang (1992) & 6.0 & & & $6 \%$ & \\
\hline 30 & Leung et al. (2005) & 6.0 & $4 \%$ & & & \\
\hline 29 & Nunally (1978) & 5.8 & & $14 \%$ & & \\
\hline 28 & Newman and Nollen (1996) & 5.6 & $4 \%$ & & & \\
\hline 28 & Erramilli and Rao (1993) & 5.6 & & & & $16 \%$ \\
\hline 27 & North (1990) & 5.4 & & $13 \%$ & & \\
\hline 27 & Brouthers and Brouthers (2001) & 5.4 & & & $5 \%$ & \\
\hline 27 & Tihanyi, Griffith and Russell (2005) & 5.4 & & & $5 \%$ & \\
\hline 27 & Barkema and Vermeulen (1997) & 5.4 & & & & $15 \%$ \\
\hline 26 & Anderson and Gatignon (1986) & 5.2 & & & & $15 \%$ \\
\hline 25 & DiMaggio and Powell (1983) & 5.0 & & $12 \%$ & & \\
\hline 25 & Johanson and Wiedersheim-Paul (1975) & 5.0 & & & $5 \%$ & \\
\hline 24 & Williamson (1985) & 4.8 & & & & $14 \%$ \\
\hline 24 & $\begin{array}{l}\text { Podsakoff, MacKenzie, Lee and Podsakoff } \\
\text { (2003) }\end{array}$ & 4.8 & & $11 \%$ & & \\
\hline 24 & Kogut and Zander (1993) & 4.8 & & & & $14 \%$ \\
\hline 24 & Hennart, and Larimo (1998) & 4.8 & & & & $14 \%$ \\
\hline 24 & Ralston, Holt, Terpstra, and Kai-Cheng (1997) & 4.8 & & $11 \%$ & & \\
\hline 23 & Hofstede (1983) & 4.6 & & $11 \%$ & & \\
\hline 23 & Aiken and West (1991) & 4.6 & $3 \%$ & & & \\
\hline
\end{tabular}


Table 2 (continued)

\begin{tabular}{|c|c|c|c|c|c|c|}
\hline $\mathbf{N}$ of citations & Reference & $\%$ & $\begin{array}{c}\text { Cluster } \\
1.1\end{array}$ & $\begin{array}{c}\text { Cluster } \\
1.2\end{array}$ & $\begin{array}{c}\text { Cluster } \\
2.1\end{array}$ & $\begin{array}{c}\text { Cluster } \\
2.2\end{array}$ \\
\hline 23 & Zaheer (1995) & 4.6 & & $11 \%$ & & \\
\hline 23 & Kostova (1999) & 4.6 & $3 \%$ & & & \\
\hline 23 & Williamson (1975) & 4.6 & & & & $13 \%$ \\
\hline 23 & Markus and Kitayama (1991) & 4.6 & $3 \%$ & & & \\
\hline
\end{tabular}

Note. \% - Percentage of citations among the 502 articles in the sample. List organized by citation frequency. Source: Based on data collected from Web of Science. (n.d.). Pesquisa básica. Retrieved from http://apps.webofknowledge.com/WOS_GeneralSearch_input.do?product=WOS\&SID=Q2VSsC8ChkihDbZkvFR\&search_ mode $=$ GeneralSearch

These 37 works were then used in the co-citation analyses (Figures 2 and 3). In drawing the cocitation maps, we followed a two-step approach: first, we drew a map with the top 16 most-cited works, and then we used the top 37 most-cited. The choice of 16 and 37 was largely arbitrary but attending to the stress of the models, as explained in the methodology section. In reading the cocitation maps of figures 2 and 3, the spatial proximity reflects co-citation ties. In other words, more proximate works are those more often co-cited. The benefit of these graphic representations is an easier visual understanding of the intellectual ties among works, arguably clearer than other visual drawings based on webs of ties.

\section{Co-citation mapping with the top 16 references}

Figure 2 comprises the 16 most-cited references. At the core is Hofstede's (1980) work as the leading reference on culture in IB studies. Looking at the spatial dispersion of the co-citations, we also identify two main study areas, which we call clusters. Cluster \# 1 (on the left side of Figure 2) contains mostly works on the concept of culture and on cultural dimensions (Hofstede, 1991; House et al., 2004; Kirkman et al., 2006; Leung et al., 2005; Schwartz, 1994; Triandis, 1995). These works largely build upon theoretical concepts derived from Hofstede's (1980) foundational study, criticizing and complementing the cultural dimensions. For instance, House et al. (2004) developed the GLOBE Project as an alternative cultural taxonomy based on Hofstede's work (Hofstede, 2006). Cluster \#1 also includes Hofstede and Bond (1988) and Ronen and Shenkar (1985), delving into cultural issues and their influence on individual behaviors and decisions.

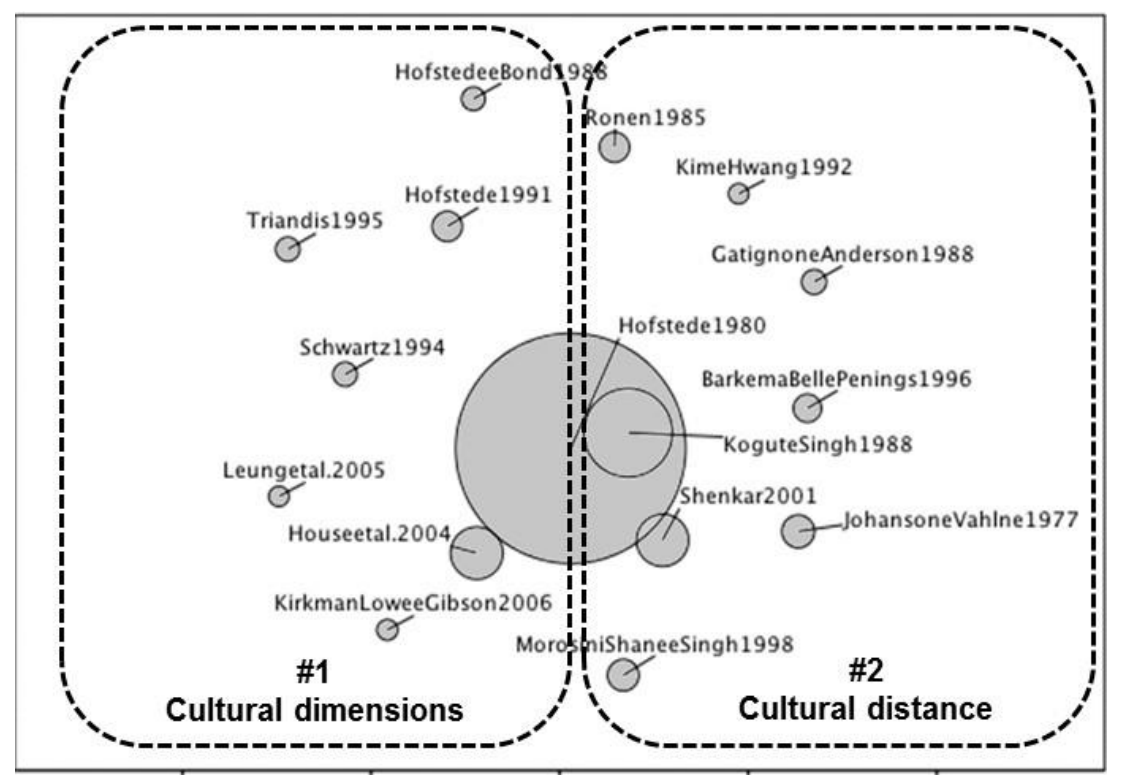

Figure 2. Co-citation Map with the Top 16 Most Cited Articles. 
Cluster \#2 (on the right side of Figure 2) comprises works dealing with the concept of cultural distance (e.g., Hofstede \& Bond, 1988; Kogut \& Singh, 1988; Shenkar, 2001) and applying it to a variety of firms' decisions, such as the internationalization process (Gatignon \& Anderson, 1988; Johanson \& Vahlne, 1977; Kim \& Hwang, 1992; Morosini et al., 1998).

\section{Co-citation mapping with the top 37 references}

The second analysis, comprising the 37 most-cited works (see Table 2), is depicted in Figure 3. Hofstede's (1980) work is still identified at the core, as the leading reference for culture in IB (the larger circle in the figure). We also observe the same two clusters in the literature; one broadly dealing with culture and cultural dimensions and another with cultural distance. What differs is that when the analysis is expanded to a greater number of articles we are able to identify four sub-clusters, two within each main cluster, and are thus able to make a more refined analysis.

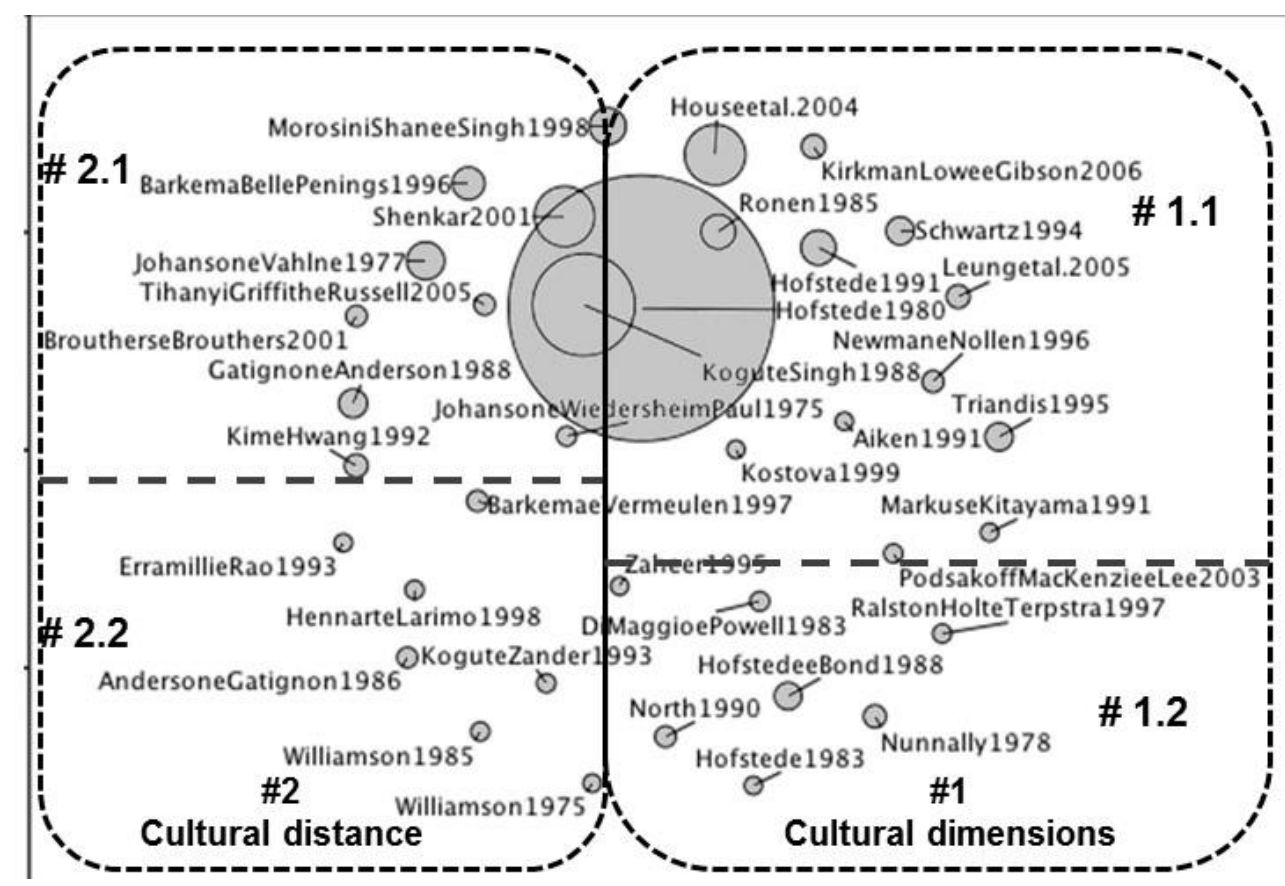

Figure 3. Co-citation Map with the Top 37 Most-Cited Articles.

\section{Sub-cluster \#1.1 - conceptual works and validation of concepts}

Sub-cluster \#1.1 - that we term as 'Conceptual works and validation of concepts' - includes works derived from Hofstede's (1980) seminal study, conceptually extending what culture is and its dimensions. Several scholars have delved into cultural and inter-cultural research: identifying characteristics, developing and testing cultural typologies. For instance, Schwartz (1994) identified seven cultural values, and House et al. (2004) advanced a taxonomy of nine cultural dimensions. These are examples of the effort to open the black box of culture by identifying and measuring cultural components. These studies have largely confirmed Hofstede's findings and validated Hofstede's cultural dimensions. Nonetheless, some scholars explored specific culture constructs, such as Triandis' (1995) study on the individualism-collectivism dimension.

A large majority of the studies extended knowledge by applying the concepts to different settings and contexts. For instance, Newman and Nollen (1996) used Hofstede's cultural dimensions to examine how managerial practices ought to be congruent with national culture. Kostova (1999), on the transfer of best practices among MNC subsidiaries, determined the importance of factors, that are at least in part culturally specific, for a successful transfer. On organizational learning, Barkema, Bell, and Penings (1996) and Barkema and Vermeulen (1998) incorporated culture-related arguments. Barkema and Vermeulen (1997) studied how Hofstede's cultural dimensions impacted international 
joint-venture survival. This line of inquiry matters because countries' cultural traits and other idiosyncratic characteristics determine how several other facets develop, such as entrepreneurial orientation, work methods, R\&D investment, and so forth.

Kirkman, Lowe and Gibson (2006) reviewed 180 articles published between 1980 and 2002 to consolidate extant empirical tests on Hofstede's four cultural dimensions. In a similar vein, Leung et al. (2005) conducted a literature review on the innovative advances made in research on culture in IB to stimulate the emergence of novel lines of research.

\section{Sub-cluster \#1.2 - cultural dimensions and an institutional approach}

Sub-cluster \#1.2 delves into culture as a component of the institutional environment (perhaps culture is better comprised in the cognitive dimension), in which institutions influence, for example, MNCs' adaptation to host-country environments in their internationalization. Some works, such as Shenkar (2001), Schwartz (1994), Hofstede and Bond (1988), House et al. (2004), Ronen and Shenkar (1985) and Trompenaars (1993) reflect the need for a greater understanding and conceptualization of culture. We include here the development of new cultural dimensions, the differences between cultural taxonomies, and how different cultural dimensions impact IB and firm decisions. To some extent, these studies involve concerns about the validity of taxonomies, comparing cultural dimensions and contrasting this with other explanations, primarily based on an institutional approach.

Progress on cultural dimensions was made in Hofstede and Bond's (1988) advancing a fifth cultural dimension - Confucian dynamism - often referred to as long-term orientation. This dimension examines how individuals deal with time and the relative importance of past, present and future in their behaviors. Hofstede (1983), in summarizing the findings on differences in work values between individuals, concluded that the usual theories about ethnocentric management based on the value systems of one single country became unsustainable. Ralston, Holt, Terpstra, and Kai-Cheng (1997) confirmed the role of national culture, noting the need to understand managers' different cultural values as a manner to promote better adaptation.

Some works connect culture to institutional theory, taking culture as an institution. DiMaggio and Powell (1983) described three isomorphic processes - coercive, normative and mimetic - to analyze external pressures firms face that may lead them to sub-optimal choices. North (1990) examined institutions, how institutions change, and their impact on economic development. North argued that institutions are based on human behavior and all institutions are created, shaped and changed by individuals. In fact, institutional differences across countries, such as cultural differences, increase the liability of foreignness (Zaheer, 1995). The key aspect is that managers cannot overlook understanding and adapting to a foreign culture.

We identified two sub-clusters within cluster \#2.

\section{Sub-cluster \#2.1 - cultural distance and entry modes}

Hofstede's (1980) work has been a hallmark in another line of research: studies on the internationalization process. These studies form sub-cluster \#2.1, on the impact of cultural distance on entry-mode research. For instance, we observe frequent co-citations between Hofstede (1980) and Johanson and Vahlne (1977) and Johanson e Wiedersheim-Paul (1975). These reflect the ties to the Uppsala School and to internationalization as a process of gradual and incremental involvement, whereby firms initially operate in culturally closer countries and with lower-risk entry modes, such as export, and gradually adopt more sophisticated entry modes, such as acquisitions and greenfield investments. The tie is thus between cultural distance and the concept of psychic distance - countries psychically distant are those with greater cultural differences, usually geographically further apart and with less similar economic profiles. Brouthers and Brouthers (2001) concluded that cultural distance gives a perception of higher investment risk, leading firms to prefer collaborative entry modes for lowrisk markets and wholly-owned subsidiaries for high-risk markets, thus proposing that investment risk 
in a foreign market moderates the impact of cultural distance on entry modes. Tihanyi et al. (2005) provided a synthesis of the extant research on the impact cultural distance has on entry modes.

In this cluster, Kogut and Singh's (1988) work emerges in a central position, highly co-cited with Hofstede. Kogut and Singh (1988) conceptualized and operationalized cultural distance, based on Hofstede's (1980) cultural dimensions. Kogut and Singh (1988) showed that national-culture characteristics influence entry-mode choices. Kogut and Singh (1988) is also highly co-cited with Shenkar's (2001) where he recommended that cultural-distance concepts and measures continue to be used and novel manners to measure distance need to be developed.

We further identified works related to learning and the choice of entry modes. Firms may seek to learn internationally and transfer the knowledge acquired internally, but cultural differences may hinder the internal transfer (Barkema, Bell, \& Penings, 1996; Morosini et al., 1998). On the other hand, cultural differences help explain why knowledge evolves differently across geographies. For instance, Morosini, Shane, and Singh (1998) showed that cultural distance improves the performance of cross-border acquisitions by providing the acquirer access to a diverse set of locally embedded knowledge and routines. Barkema et al. (1996), examining entry modes, ownership structure and cultural distance, concluded that firms face cultural barriers when expanding internationally but by learning from prior experiences, they are able to improve performance in future deals. The idea that we ought to focus more on cultural differences rather than on absolute cultural indexes has gained many followers.

\section{Sub-cluster \#2.2 - cultural distance and transaction costs in internationalization}

Sub-cluster \#2.2 includes works related to Transaction Cost Theory (TCT). The use of TCTbased explanations by IB scholars on entry-mode and location selection, reflects the economics tradition of IB research. The concept and studies of cultural distance have supported entry-mode and FDI explanations, using TCT-based arguments (Gatignon \& Anderson, 1988; Hennart, 1988; Hennart \& Larimo, 1998; Kim \& Hwang, 1992). One broad argument is that the greater the cultural distance, the larger the degree of control over the foreign operations required by MNEs. This choice might mean, for example, that firms prefer a joint-venture (Erramilli \& Rao, 1993) over export. Moreover, larger cultural distances entail higher transaction costs and greater difficulty in transferring skills and knowledge among subsidiaries or between the HQ and subsidiaries (Barkema \& Vermeulen, 1998). To overcome transaction costs, firms may internalize foreign operations (Hennart, 1991).

Differences between countries increase the risk of foreign operations and heighten transaction costs. Firms face high transaction costs when internationalizing into countries with very different cultures (Erramilli \& Rao, 1993; Gatignon \& Anderson, 1988; Kim \& Hwang, 1992; Williamson, 1975, 1985). Anderson and Gatignon (1986) presented a framework of transaction costs in research into entry modes. Gatignon and Anderson (1988) examined how transaction costs could impact the ownership strategy for foreign subsidiaries. Hennart and Larimo (1998) empirically tested some determinants of entry modes into the US and concluded that cultural distance between home and host country impacted the ownership strategy for foreign subsidiaries, whereas the cultural traits of the home country had no impact on the ownership choices pursued.

\section{Discussion}

In this paper we examined extant IB research to specifically observe the extent to which it has incorporated culture and how culture has been integrated into it. Hence, our purpose was neither to define culture, something that may be found in existing works, nor to discuss how culture measurements have been operationalized (see Taras et al., 2009). We identified ties among works and revealed their positioning in co-citation maps, thus observing clusters of research streams. Methodologically, we conducted a bibliometric study of over five hundred articles published in the top 
seven journals for IB research between 1966 and 2012. With this study we complement existing literature reviews and bibliometric and bibliographic analyses (Leung et al., 2005; Taras et al., 2009). This study is especially useful for new IB scholars and post-graduate students. Often researchers need to examine the wisdom received and make sense of the stock of accumulated knowledge on a given topic or the development of a theory (Guarido, Machado-da-Silva, \& Gonçalves, 2009; Guarido, Machado-da-Silva, \& Rossoni, 2010). These studies permit consolidating the extant knowledge and also identifying gaps to nurture future research arenas. For young scholars and doctoral students this study presents an overall picture of how IB research has been permeated by culture and its main streams of emphasis in such a manner that they may gain a broad understanding of this stock of knowledge.

A number of immediate results warrant brief attention. The results using the 37 most-cited articles (Figure 3) reveal four main research streams (or clusters) that we synthesize in a conceptual framework (Figure 4). These clusters seem to derive from Hofstede's work. Regarding the centrality of Hofstede's work, despite the emergence of alternative cultural taxonomies such as the GLOBE project and the discussion on what culture is, its dimensions, how to measure it, and so forth, Hofstede's influence is recognized beyond the academia. A recent ranking of the Wall Street Journal, May 2008, on the most influential thinkers in Management, identified Hofstede as the sixteenth most influential, following others such as Gary Hamel, Thomas Friedman, Philip Kotler, Henry Mintzberg, Michael Porter, and before Clayton Christensen, Jack Welch and Tom Peters. Examining citation data of the core management journals shows that Hofstede's work, and especially his 1980 book Culture consequences: International differences in work-related values, are among the most cited in management.

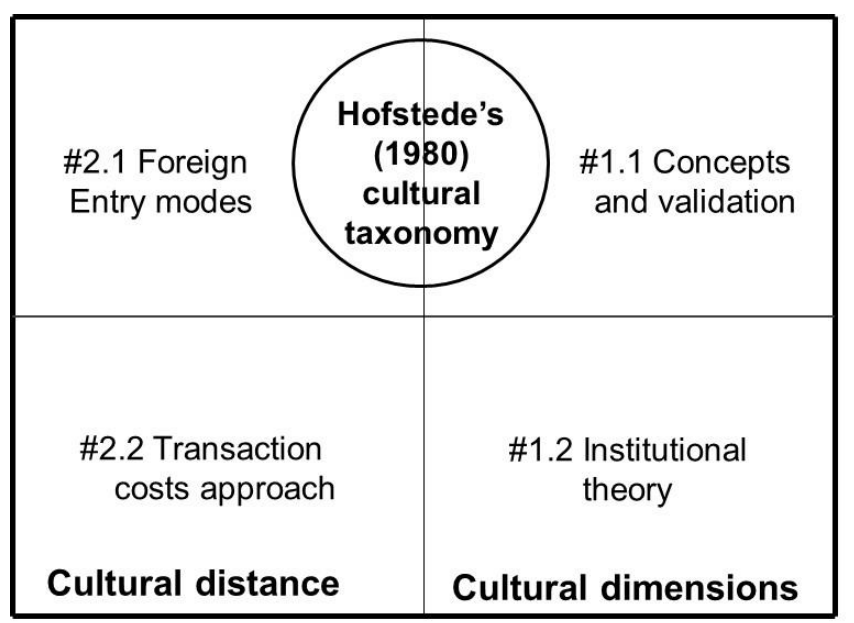

Figure 4. Conceptual Framework of Culture in IB Research.

Why does Hofstede's work stand out? Hofstede's seminal work changed the way most IB research was conducted, and created a lasting debate on the conceptualization and measurement issues surrounding cultural aspects (Taras et al., 2009). Albeit there were other studies quantifying several aspects of culture, it was only with the publication of Culture's consequences by Hofstede (1980) that the interest into culture measurement took off. Hofstede showed that culture could be measured and used in empirical comparisons across countries. Before Hofstede (1980), research on crosscultural and international issues tended to treat culture as a black box construct. Mostly, culture was treated as a single (or one-dimensional) variable, and as something that was outside the firm and could not be measured. Thus, culture's impact was assumed and firms' decisions, practices and results were posited to vary due to the effects of cultural idiosyncrasies, without actually measuring these differences (Ferreira et al., 2009). Hofstede's work showed it was possible to disaggregate culture and proposed four cultural dimensions; later adding a fifth (Hofstede \& Bond, 1988) and sixth (Hofstede, Hofstede, \& Minkov, 2010). This disaggregation allowed a better understanding of the components of culture and fed countless studies on the impact of each cultural dimension on different actions and individual and MNC aspects. Finally, Hofstede's work was a foundation for other cultural models and 
taxonomies, such as Schwartz's (1994) research on values and the GLOBE project's (House et al., 2004) focus on cultural attributes (see also Javidan et al., 2006; Kirkman et al., 2006).

Examining the four clusters of research, we noted that one (\#1.1) is broadly related to the concept of culture and its dimensions, including theoretical and empirical works improving upon, criticizing, testing or adding novel cultural dimensions. It further included a conceptual discussion of what culture is and how to measure it (for details on measurement issues see Taras et al., 2009). A second stream (\#1.2) pertains to cultural dimensions, often with an institutional approach. This line of inquiry takes culture as a component of the institutional environment in which firms conduct business and its influence on entry modes, governance, HR practices, and other aspects relevant to internationalization. The third (\#2.1) delves into the relationship between cultural distance and entry modes. The fourth (\#2.2) is more centered on transaction cost theory associated with entry modes and strategies, often resorting to psychic and cultural-distance concepts.

A major stream in the extant research has used institutional lenses. The institutional environment of MNCs has been a prominent research topic in IB studies, and more recently involving emerging economies, because institutions influence MNCs' strategic choices (Kostova, 1999). Hofstede (1984) argued that culture distinguishes groups of people and contributes to differentiate countries' institutional environments. Culture influences individuals, and individuals construct and maintain institutions (Amable, 2003; Hofstede, 1984). North (1990) discussing the role of culture on institutions and institutional development, noted that "the cultural filter provides continuity so that the informal solution to exchange problems in the past carries over into the present and makes those informal constraints important sources of continuity in long-run societal change" (p. 37). Berry et al. (2010) contended that while formal institutions refer to economic, political and regulatory institutions, informal institutions include cultural institutions. Daniel, Cieslewicz, and Pourjalali (2012) argued that cultural influences on business practices are indirect, through the development of institutional systems. Hence, culture seems to permeate and contribute to build the institutional environment.

The institutional differences across countries occupy a prominent place in IB research (Salomon $\& \mathrm{Wu}, 2012)$ and impact the way firms do business. Some scholars conceptualized and measured the construct (Berry, Guillén, \& Zhou, 2010; Brouthers \& Brouthers, 2000; Salomon \& Wu, 2012) while others have connected it to an array of firms' decisions, such as entry modes (Yiu \& Makino, 2002), location choices (Holburn \& Zelner, 2010), local isomorphic strategies (Salomon \& Wu, 2012), access to complementary resources (Morosini et al., 1998) and developing capabilities and learning (Barkema et al., 1996).

Although this line of inquiry is already densely populated, there are many future avenues to deepen our knowledge. For instance, to better understand the relations between culture as an institution and the dimensions of distance and specific firm-level strategies. In fact, differences across countries are sources of uncertainty, and firms strategize differently to cope with uncertainty. Moreover, national culture and institutional environments are separate constructs and it might be interesting to examine the institutional environment as a mediating and moderating variable alongside culture when examining business practices and characteristics (Daniel et al., 2012). Relative to institutional distance and firms' mimetic behaviors, we should inquire whether more distant foreign affiliates are more or less likely to imitate foreign rivals that are similar to them on one or more dimensions as opposed to domestic firms, or vice versa. How recent disruptions in political, social and economic orders around the world reflect changes in the institutional arrangements and how these impact MNCs has been sparsely studied. That is, institutions, as culture, evolve over time both gradually and in a disruptive manner in response to abrupt changes. Finally, we need to better understand the sources of heterogeneity across countries and how these drive institutional differences and change.

Transaction cost theory is another important theoretical foundation in which much IB research, including culture-related, has been sustained, such as foreign entry modes, market selection, partnering choices, and beyond (Maekelburger, Schwens, \& Kabst, 2012). Brouthers and Hennart (2007) argued that TCT "is the most widely used theoretical perspective in international entry mode research and 
appears in almost half of the studies" (p. 400). Shenkar (2001, 2012) explained the intellectual tie between culture and TCT, noting that cultural distance is the major source of contextual and behavioral uncertainty in host countries, leading to transaction costs that may affect foreign direct investment, market-entry strategies and firm performance. Firms that have operations in a host country face disadvantages and additional costs relative to their domestic counterparts (Hymer, 1976; Salomon \& Martin, 2008; Zaheer, 1995). These added costs are related to operating in unfamiliar geographies, and firms strategize to minimize them by selecting amongst the entry-mode alternatives (Brouthers \& Hennart, 2007).

The attributes that characterize transactions - asset specificity, uncertainty and frequency (Williamson, 1985) - create transaction costs, making internalization more efficient and more attractive. Erramilli and Rao (1993) suggested that cultural distance does not raise transaction costs sufficiently to impact on the relationship between asset specificity and entry- mode choice. In contrast, Maekelburger, Schwens, and Kabst (2012) showed that cultural proximity is a significant moderator of the relationship between asset specificity and entry-mode choice. Geographic, cultural and psychic distances are all proxies for differences across countries that contribute to gestate uncertainty and hazards for firms needing to communicate, manage and monitor the transactions in a distant country. In fact, Brouthers and Brouthers (2000) proposed that transaction cost theory, specifically when applied to entry-mode choices, could be extended by using institutional and cultural variables as an underlying context. Nonetheless, future research is still needed, for instance, to understand the relationship between asset specificity and culture. In emerging economies research, transaction costs seem to be higher for developed country multinationals due to the institutional voids and cultural differences that raise risks and total transaction costs (Uhlenbruck, 2004).

\section{Limitations and future research}

Some limitations of this study warrant a note. First, and perhaps the easiest to overcome in future research is the selection of journals. Albeit we selected the most reputed journals for IB research, and those more likely to drive the evolution of the discipline, there are many other outlets. Future studies may extend the sample to include journals on general management, journals that are specific to other disciplines - namely strategic management, international marketing, cross-cultural management - and journals on specific themes, such as business ethics. In fact, constructs and theories are used differently in different disciplines and with different goals, and novel findings may appear on how pervasive culture-related research has been in other disciplines.

Other limitations are specific to bibliometric methods. Examining citations and co-citations is interesting and allows dealing with a large volume of data, but it is difficult to truly grasp why a given citation was made without a content analysis (Ramos-Rodríguez \& Ruíz-Navarro, 2004). Moreover, we observe the strong centrality of Hofstede's work. At least some citations to Hofstede (1980) may be merely ceremonial or to position a paper in the IB discipline. We cannot assess authors' intentions when citing this work but we are aware that authors may cite a given work for a variety of reasons. For instance, to build upon the arguments, to criticize, to contrast or to complement. This shortcoming may be overcome in future research with an in-depth content analysis that is able to disentangle the context in which citations are made, the frequency of citations, and whether culture appears as the dependent variable, independent variable (Pothukuchi et al., 2002), as a moderator (Newman \& Nollen, 1996) or as a control.

The data used was collected from ISI web of knowledge which, albeit its high reputation, has some gaps in the reporting of some journals and data. For example, there was an eighteen-year gap (from 1990 to 2008) in the coverage of Management International Review. Despite these limitations, we are confident that the sample is representative of the extant IB research. This limitation may be overcome by employing alternative databases such as Scopus, and using additional source documents such as books, conference proceedings, and so forth. It is worth noting that Hofstede's (1980) work is the most cited and it is a book, not an article. 
There are a number of future research possibilities to further explore culture in IB studies. We identified strong connections between culture and some of the main research themes in IB. For instance, the ties with foreign entry modes and transaction costs - reflecting the difficulties and risks firms face when internationalizing. However, we failed to identify a connection with the ResourceBased View, which has been a fast-growing theoretical perspective in management studies. The ability to overcome cultural barriers might in itself be a valuable capability. Future research could seek to understand the impact national culture has on how firms may develop a pool of valuable resources.

Additional studies may also discuss and explore how the cultural issues that influence much of IB thought (e.g., Triandis, 2004) have been insufficiently explored in some domains. For instance, culture has been rarely used to understand the integration of expatriates and the choice of which expatriates to use in each country. Expatriates face multiple challenges, from cultural barriers to the management of relationships with clients, suppliers, workers and other stakeholders. In fact, culture is relevant not only for expatriates but to all professionals that interact with individuals from other cultures regardless of where they are located (Triandis, 2004). Inter-cultural differences may help understand firms' choices concerning the use of expatriates (Brock, Shenkar, Shoham, \& Siscovick, 2008) but more research is needed.

\section{Concluding Remarks}

We conclude there exists a pervasiveness of culture-related research in IB studies. This is especially so after 1980, to which we attribute Hofstede's (1980) seminal piece, and even more prominent from the mid-1990s onwards. Culture and cultural dissimilarities among countries are embedded in much IB research, but studies delving into cultural aspects permeate various other disciplines. Following Ferreira et al. (2009), culture is perhaps one of the core contextual dimensions of the international business environment that impacts firms' strategies and operations.

To conclude, neither scholars nor practitioners would deny the relevance of culture for IB operations. There is still ample space for researchers to understand how each cultural trait influences specific firms' actions. We expect that IB research will continue to intensively use cultural dimensions and dissimilarities. For managers, the challenge has been in identifying cultural differences among countries and how these impact firms' operations, to assess the best organizational models, managerial practices, and partnerships that might improve performance abroad. Concurrently, scholars seem to understand the very concept of culture, identify what it comprises, and understand whether national cultures are converging to a universal set of values, norms, beliefs and behaviors. As cultures are in constant flux, novel challenges are emerging to drive yet more research in this area.

\section{References}

Acedo, F. J., Barroso, C., \& Galan, J. L. (2006). The resource - based theory: dissemination and main trends. Strategic Management Journal, 27(7), 621-636. doi: 10.1002/smj.532

Acedo, F. J., \& Casillas, J. C. (2005). Current paradigms in the international management field: an author co-citation analysis. International Business Review, 14(5), 619-639. doi: 10.1016/j.ibusrev.2005.05.003

Adler, N. J. (1983). Cross-cultural management research: the ostrich and the trend. Academy Management Review, 8(2), 226-232. doi: 10.2307/257749

Aiken, L., \& West, S. (1991). Multiple regression: testing and interpreting interactions. Newbury Park: Sage. 
Amable, B. (2003). The diversity of modern capitalism. Oxford: Oxford University Press.

Anderson, E., \& Gatignon, H. (1986). Modes of foreign entry: a transaction cost analysis and propositions. Journal of International Business Studies, 17(3), 1-26. doi: 10.1057/palgrave.jibs. 8490432

Barkema, H. G., Bell, J. H. J., \& Penings, J. M. (1996). Foreign entry, cultural barriers, and learning. Strategic Management Journal, 17(2), 151-166. doi: 10.1002/(SICI)10970266(199602)17:2<151::AID-SMJ799>3.0.CO;2-Z

Barkema, H. G., \& Vermeulen, F. (1997). What differences in the cultural backgrounds of partners are detrimental for international joint ventures? Journal of International Business Studies, 28(4), 845-864. doi: 10.1057/palgrave.jibs.8490122

Barkema, H. G., \& Vermeulen, F. (1998). International expansion through start-up or acquisition: a learning perspective. Academy of Management Journal, 41(1), 7-26. doi: 10.2307/256894

Bellis, N. (2009). Bibliometrics and citation analysis: from the science citation index to cybermetrics. Plymouth, UK: Scarecrow Press.

Berry, H., Guillén, M. F., \& Zhou, N. (2010). An institutional approach to cross-national distance. Journal of International Business Studies, 41(9), 1460-1480. doi: 10.1057/jibs.2010.28

Boyacigiller, N., \& Adler, N. (1997). Insiders and outsiders: bridging the worlds of organizational behavior and international management. In B. Toyne \& D. Nigh (Eds.), International business: an emerging vision (pp. 396-416). Columbia, SC: University of South Carolina Press.

Brewer, P., \& Venaik, S. (2011). Individualism-collectivism in Hofstede and GLOBE. Journal of International Business Studies, 42(3), 436-445. doi: 10.1057/jibs.2010.62

Brock, D. M., Shenkar, O., Shoham, A., \& Siscovick, I. C. (2008). National culture and expatriate deployment. Journal of International Business Studies, 39(8), 1293-1309. doi: 10.1057/palgrave.jibs.8400361

Brouthers, K. D., \& Brouthers, L. E. (2000). Acquisition or greenfield start-up? Institutional, cultural and transaction cost influences. Strategic Management Journal, 21(1), 89-97. doi: 10.1002/(SICI)1097-0266(200001)21:1<89::AID-SMJ85>3.0.CO;2-8

Brouthers, K. D., \& Brouthers, L. E. (2001). Explaining the national cultural distance paradox. Journal of International Business Studies, 32(1), 177-189. doi: 10.1057/palgrave.jibs.8490944

Brouthers, K. D., \& Hennart, J.-F. (2007). Boundaries of the firm: insights from international entry mode research. Journal of Management, 33(3), 395-425. doi: 10.1177/0149206307300817

Chakrabarti, R., Gupta-Mukherjee, S., \& Jayaraman, N. (2009). Mars-Venus marriages: culture and cross-border M\&A. Journal of International Business Studies, 40(2), 216-236. doi: $10.1057 /$ jibs.2008.58

Chandy, P., \& Gopalakrishna, P. (1992). A content analysis of contributions to the Management International Review Journal. Management International Review, 32(3), 273-283.

Chandy, P. R., \& Williams, T. G. E. (1994). The impact of journals and authors on international business research: a citational analysis of JIBS articles. Journal of International Business Studies, 25(4), 715-728. doi: 10.1057/palgrave.jibs.8490221

Cronin, B. (2001). Bibliometrics and beyond: some thoughts on web-based citation analysis. Journal of Information Science, 27(1), 1-7. doi: 10.1177/016555150102700101 
Daniel, S. J., Cieslewicz, J. K., \& Pourjalali, H. (2012). The impact of national economic culture and country-level institutional environment on corporate governance practices. Management International Review, 52(3), 365-394. doi: 10.1007/s11575-011-0108-x

DiMaggio, P. J., \& Powell, W. W. (1983). The iron cage revisited institutional isomorphism and collective rationality in organizational fields. American Sociological Review, 48(2), 143-166. doi: 10.1016/S0742-3322(00)17011-1

Dow, D., \& Karunaratna, A. (2006). Developing a multidimensional instrument to measure psychic distance stimuli. Journal of International Business Studies, 37(5), 578-602. doi: 10.1057/palgrave.jibs. 8400221

DuBois, F., \& Reeb, D. (2000). Ranking the international business journals. Journal of International Business Studies, 31(4), 689-704. doi: 10.1057/palgrave.jibs.8490929

Earley, P., \& Gibson, C. (1998). Taking stock in our progress on individualism-collectivism: 100 years of solidarity and community. Journal of Management, 24(3), 265-304. doi: $10.1177 / 014920639802400302$

Erramilli, M. K., Agarwal, S., \& Kim, S.-S. (1997). Are firm-specific advantages location-specific too? Journal of International Business Studies, 28(4), 735-757. doi: 10.1057/palgrave.jibs. 8490117

Erramilli, M. K., \& Rao, C. P. (1993). Service firms' international entry mode choice: a modified transaction-costs analysis approach. Journal of Marketing, 57(3), 19-38.

Ferreira, M. P. (2011). A bibliometric study on Ghoshal's managing across borders. Multinational Business Review, 19(4), 357-375. doi: 10.1108/15253831111190180

Ferreira, M. P., Li, D., Guisinger, S., \& Serra, F. A. R. (2009). Is the international business environment the actual context for international business research? Revista de Administração de Empresas, 49(3), 282-294. doi: 10.1590/S0034-75902009000300004

Fischer, R., \& Mansell, A. (2009). Commitment across cultures: a meta-analytical approach. Journal of International Business Studies, 40(8), 1339-1358. doi: 10.1057/jibs.2009.14

Gatignon, H., \& Anderson, E. (1988). The multinational corporation's degree of control over foreign subsidiaries: an empirical test of a transaction cost explanation. Journal of Law, Economics and Organization, 4(2), 305-336.

Gómes-Mejia, L., \& Palich, L. E. (1997). Cultural diversity and the performance of multinational firms. Journal of International Business Studies, 28(2), 309-335. doi: 10.1057/palgrave.jibs.8490103

Griffith, D. A., Cavusgil, S. T., \& Xu, S. (2008). Emerging themes in international business research. Journal of International Business Studies, 39(7), 1220-1235. doi: 10.1057/palgrave.jibs.8400412

Guarido, E. R., Filho, Machado-da-Silva, C. L., \& Gonçalves, S. A. (2009). Organizational institutionalism in the academic field in Brazil: social dynamics and networks. Brazilian Administration Review, 6(4), 299-315. Retrieved from http://www.scielo.br/pdf/bar/v6n4/v6n4a03.pdf. doi: 10.1590/S1807-76922009000400003

Guarido, E. R., Filho, Machado-da-Silva, C. L., \& Rossoni, L. (2010). The social and intellectual dimensions in the construction of scientific knowledge: the institutional theory in organization studies in Brazil. Brazilian Administration Review, 7(2), 136-154. Retrieved from http://www.scielo.br/pdf/bar/v7n2/v7n2a03.pdf. doi: 10.1590/S1807-76922010000200003 
Gupta, V., \& House, R. (2004). Understanding leadership in diverse cultures: implications of project GLOBE for leading international ventures. In D. Tjosvold \& K. Leung (Eds.), Leading in High Growth Asia: managing relationship for teamwork and change (pp. 13-54). Singapore: World Scientific Publishing.

Hall, E. (1976). Beyond culture. New York: Doubleday.

Harzing, A-W. (2014, February 11). Journal Quality List (52th ed.). Australia. Retrieved from http://www.harzing.com/download/jq1_journal.pdf

Harzing, A.-W., \& Wal, R., van der (2009). A Google Scholar h-index for journals: an alternative metric to measure journal impact in economics and business. Journal of the American Society for Information Science and Technology, 60(1), 41-46. doi: 10.1002/asi.v60:1

Hennart, J-F. (1988). A transaction costs theory of equity joint ventures. Strategic Management Journal, 9(4), 361-374. doi: 10.1002/smj.4250090406

Hennart, J.-F. (1991). The transaction costs theory of joint ventures: an empirical study of Japanese subsidiaries in the United States. Management Science, 37(4), 483-497.

Hennart, J-F., \& Larimo, J. (1998). The impact of culture on the strategy of multinational enterprises: does national origin affect ownership decisions? Journal of International Business Studies, 29(3), 515-538. doi: 10.1057/palgrave.jibs.8490005

Hofstede, G. (1980). Culture's consequences: international differences in work-related values. Newbury Park, CA: Sage.

Hofstede, G. (1983). The cultural relativity of organizational practices and theories. Journal of International Business Studies, 14(2), 75-89. doi: 10.1057/palgrave.jibs.8490867

Hofstede, G. (1984). Culture's consequences: international differences in work-related values. Newbury Park, CA: Sage Publications.

Hofstede, G. (1991). Culture and organizations: software of the mind. New York: McGraw-Hill.

Hofstede, G. (1994). Management scientists are human. Management Science, 40(1), 4-13. doi: 10.1287/mnsc.40.1.4

Hofstede, G. (2006). What did GLOBE really measure? Researchers' minds versus respondents' minds. Journal of International Business Studies, 37(6), 882-896. doi: 10.1057/palgrave.jibs. 8400233

Hofstede, G., \& Bond, M. H. (1988). The confucious connection: from cultural roots to economic growth. Organizational Dynamics, 16(4), 5-21. doi: 10.1016/0090-2616(88)90009-5

Hofstede, G., \& Hofstede, G. (1991). Cultures and organizations software of the mind. Berkshire, UK: McGraw Hill.

Hofstede, G., Hofstede, G., \& Minkov, M. (2010). Cultures and organizations: software of the mind (3rd ed.). New York, USA: McGraw-Hill.

Holburn, G., \& Zelner, B. (2010). Political capabilities, policy risk, and international investment strategy: evidence from the global electric power generation industry. Strategic Management Journal, 31(12), 1290-1315. doi: 10.1002/smj.860

House, R., Hanges, P., Javidan, M., Dorfman, P., \& Gupta, V. (Eds.). (2004). GLOBE, cultures, leadership, and organizations: GLOBE study of 62 societies. Newbury Park, CA: Sage Publications. 
House, R., Hanges, P., Ruiz-Quintanilha, S., Dorfman, P., Javidan, M., Dickson, M., \& Gupta, V. (1999). GLOBE: cultural influences on leadership and organizations. In W. Mobley, M. Gessner, \& V. Arnald (Eds.), Advances in global leadership (Vol.1, pp. 171-233). Stanford, CT: JAI Press.

Hymer, S. (1976). The international operations of national firms: a study of direct foreign investment. Cambridge, MA: MIT Press.

Inkpen, A. C., \& Beamish, P. W. (1994). An analysis of twenty-five years of research in the journal of international business studies. Journal of International Business Studies, 25(4), 703-713. doi: 10.1057/palgrave.jibs. 8490220

Ito, S., Fujimura, S., \& Tamiya, T. (2012). Does cultural assimilation affect organizational decisionmaking on quality-related incidents? A company's post-M\&A experience. Journal of International Management, 18(2), 160-179. doi: 10.1016/j.intman.2012.02.004

Javidan, M., House, R. J., Dorfman, P. W., Hanges, P. J., \& Luque, M. S. de (2006). Conceptualizing and measuring cultures and their consequences: a comparative review of GLOBE's and Hofstede's approaches. Journal of International Business Studies, 37(6), 897-914. doi: $10.1057 /$ palgrave.jibs. 8400234

Johanson, J., \& Vahlne, J. (1977). The internationalization process of the firm: a model of knowledge development and increasing foreign market commitments. Journal of International Business Studies, 8(1), 23-32. doi: 10.1057/palgrave.jibs.8490676

Johanson, J., \& Vahlne, J.-E. (1990). The mechanism of internationalization. International Marketing Review, 7(4), 11-24. doi: 10.1108/02651339010137414

Johanson, J., \& Wiedersheim-Paul, F. (1975). The internationalization of the firm: four Swedish cases. Journal of Management Studies, 12(3), 305-323. doi: 10.1111/j.1467-6486.1975.tb00514.x

Kang, J.-K., \& Kim, J.-M. (2010). Do foreign investors exhibit a corporate governance disadvantage? An information asymmetry perspective. Journal of International Business Studies, 41(8), 14151438. doi:10.1057/jibs.2010.18

Kim, W. C., \& Hwang, P. (1992). Global strategy and multinationals' entry mode choice. Journal of International Business Studies, 23(1), 29-53. doi: 10.1057/palgrave.jibs.8490258

Kirkman, B. L., Lowe, K. B., \& Gibson, C. B. (2006). A quarter century of culture's consequences: a review of empirical research incorporating Hofstede's cultural values framework. Journal of International Business Studies, 37(3), 285-320. doi: 10.1057/palgrave.jibs.8400202

Kogut, B., \& Singh, H. (1988). The effect of national culture on the choice of entry mode. Journal of International Business Studies, 19(3), 411-432. doi: 10.1057/palgrave.jibs.8400136

Kogut, B., \& Zander, U. (1993). Knowledge of the firm and the evolutionary theory of the multinational corporation. Journal of International Business Studies, 24(4), 625-645. doi: 10.1057/palgrave.jibs. 8490248

Kostova, T. (1999). Transnational transfer of strategic organizational practices: a contextual perspective. The Academy of Management Review, 24(2), 308-324. doi: 10.5465/AMR.1999.1893938

Leung, K., Baghat, R. S., Buchan, N. R., Erez, M., \& Gibson, C. B. (2005). Culture and international business: Recent advances and their implications for future research. Journal of International Business Studies, 36(4), 357-378. doi: 10.1057/palgrave.jibs.8400150 
Maekelburger, B., Schwens, C., \& Kabst, R. (2012). Asset specificity and foreign market entry mode choice of small and medium-sized enterprises: the moderating influence of knowledge safeguards and institutional safeguards. Journal of International Business Studies, 43(5), 458476. doi: $10.1057 /$ jibs. 2012.12

Markus, H., \& Kitayama, S. (1991). Culture and the self: Implications for cognition, emotion, and motivation. Psychological Review, 98(2), 224-253.

Meyer, J., Boli, J., Thomas, G., \& Ramirez, F. (1997). World society and the nation-state. American Journal of Sociology, 103(1), 144-181. doi: 10.1086/231174

Michailova, S., \& Minbaeva, D. B. (2012). Organizational values and knowledge sharing in multinational corporations: the danisco case. International Business Review, 21(1), 59-70. doi: 10.1016/j.ibusrev.2010.11.006

Minkov, M., \& Hofstede, G. (2011). The evolution of Hofstede's doctrine. Cross Cultural Management: an International Journal, 18(1), 10-20. doi: 10.1108/13527601111104269

Morosini, P., Shane, S., \& Singh, H. (1998). National cultural distance and cross-border acquisition performance. Journal of International Business Studies, 29(1), 137-158. doi: 10.1057/palgrave.jibs.8490029

Newman, K. L., \& Nollen, S. D. (1996). Culture and congruence: the fit between management practices and national culture. Journal of International Business Studies, 27(4), 753-779. doi: 10.1057/palgrave.jibs.8490152

North, D. (1990). Institutions, institutional change and economic performance. Cambridge: UK: Cambridge University Press.

Nunally, J. (1978). Psychometric theory (2nd ed.). New York: McGraw-Hill.

Oyserman, D., Coon, H. M., \& Kemmelmeier, M. (2002). Rethinking individualism and collectivism: evaluation of theoretical assumptions and meta-analyses. Psychological Bulletin, 128(1), 3-72. doi: 10.1037/0033-2909.128.1.3

Peng, M. W., \& Zhou, J. Q. (2006). Most cited articles and authors in global strategy research. Journal of International Management, 12(4), 490-508. doi: 10.1016/j.intman.2006.04.001

Pilkington, A., \& Meredith, J. (2009). The evolution of the intellectual structure of operations management 1980-2006: a citation/co-citation analysis. Journal of Operations Management, 27(3), 185-202. doi: 10.1016/j.jom.2008.08.001

Podsakoff, P. M., MacKenzie, S. B., Lee, J.-Y., \& Podsakoff, N. P. (2003). Common method biases in behavioral research: a critical review of the literature and recommended remedies. Journal of Applied Psychology, 88(5), 879-903. doi: 10.1037/0021-9010.88.5.879

Pothukuchi, V., Damanpou, F., Choi, J., Chen, C. C., \& Park, S. H. (2002). National and organization culture differences and international joint venture performance. Journal of International Business Studies, 33(2), 243-265. doi: 10.1057/palgrave.jibs.8491015

Ralston, D. A., Egri, C. P., Carranza, M. T. G. de la, Ramburuth, P., Terpstra-Tong, J., Pekerti, A. A., Girson, I., Herrig, H., Dabic, M., Tang, M. et al. (2009). Ethical preferences for influencing superiors: a 41-society study. Journal of International Business Studies, 40(6), 1022-1045. doi: 10.1057/jibs.2008.109

Ralston, D. A., Holt, D. H., Terpstra, R. H., \& Kai-Cheng, Y. (1997). The impact of national culture and economic ideology on managerial work values: a study of the United States, Russia, Japan, 
and China. Journal of International Business Studies, 28(1), 177-208. doi: 10.1057/palgrave.jibs. 8490097

Ramos-Rodríguez, A.-R., \& Ruíz-Navarro, J. (2004). Changes in the intellectual structure of strategic management research: a bibliometric study of the Strategic Management Journal, 19802000. Strategic Management Journal, 25(10), 981-1004. doi: 10.1002/smj.397

Robinson, S. L., \& Bennett, R. J. (1995). A typology of deviant workplace behaviors: a multidimensional scaling study. Academy of Management Journal, 38(2), 555-572. doi: $10.2307 / 256693$

Ronen, S., \& Shenkar, O. (1985). Clustering countries on attitudinal dimensions: a review and synthesis. Academy of Management Review, 10(3), 435-454. doi: 10.5465/AMR.1985.4278955

Rubera, G., Ordanini, A., \& Griffith, D. A. (2011). Incorporating cultural values for understanding the influence of perceived product creativity on intention to buy: an examination in Italy and the US. Journal of International Business Studies, 42(4), 459-476. doi: 10.1057/jibs.2011.3

Salomon, R., \& Martin, X. (2008). Learning, knowledge transfer and technology implementation performance: a study of time-to-build in the global semiconductor industry. Management Science, 54(7), 1266-1280. doi 10.1287/mnsc.1080.0866

Salomon, R., \& Wu, Z. (2012). Institutional distance and local isomorphism strategy. Journal of International Business Studies, 43(4), 343-367. doi: 10.1057/jibs.2012.3

Sarala, R. M., \& Vaara, E. (2010). Cultural differences, convergence, and crossvergence as explanations of knowledge transfer in international acquisitions. Journal of International Business Studies, 41(8), 1365-1390. doi: 10.1057/jibs.2009.89

Scholtens, B., \& Dam, L. (2007). Cultural values and international differences in business ethics. Journal of Business Ethics, 75(3), 273-284. doi: 10.1007/s10551-006-9252-9

Schwartz, S. (1994). Beyond individualism/collectivism: new dimensions of values. In U. Kim, H. Triandis, C. Kagitcibasi, S. Choi, \& G. Yoon (Eds.), Individualism and collectivism: theory, method, and applications (pp. 85-111). Newbury Park, CA: Sage.

Shenkar, O. (2001). Cultural distance revisited: towards a more rigorous conceptualization and measurement of cultural differences. Journal of International Business Studies, 32(3), 519-535. doi: $10.1057 /$ palgrave.jibs. 8490982

Shenkar, O. (2012). Cultural distance revisited: towards a more rigorous conceptualization and measurement of cultural differences. Journal of International Business Studies, 43(1), 1-11. doi: $10.1057 /$ jibs. 2011.40

Smith, P., Peterson, M., \& Schwartz, S. (2002) Cultural values, source of guidance, and their relevance to managerial behavior: a 47-nation study. Journal of Cross-Cultural Psychology, 33(2), 188-208. doi: 10.1177/0022022102033002005

Taras, V., Rowney, J., \& Steel, P. (2009). Half a century of measuring culture: review of approaches, challenges, and limitations based on the analysis of 121 instruments for quantifying culture. Journal of International Management, 15(4), 357-373. doi: 10.1016/j.intman.2008.08.005

Thomson Reuters. (2014). Web of Science. Retrieved from http://thomsonreuters.com/products/ipscience/04_062/wos-next-gen-brochure.pdf

Tihanyi, L., Griffith, D. A., \& Russell, C. J. (2005). The effect of cultural distance on entry mode choice, international diversification, and MNE performance: a meta-analysis. Journal of International Business Studies, 36(3), 270-283. doi: 10.1057/palgrave.jibs.8400136 
Treviño, L. J., Mixon, F. G., Jr., Funk, C. A., \& Inkpen, A. C. (2010). A perspective on the state of the field: international business publications in the elite journals as a measure of institutional and faculty productivity. International Business Review, 19(4), 378-387. doi: 10.1016/j.ibusrev.2010.02.004

Triandis, H. C. (1995). Individualism e collectivism. New directions in social psychology. Boulder, CO, US: Westview Press.

Triandis, H. C. (2004). The many dimensions of culture. The Academy of Management Executive, 18(1), 88-93. doi: 10.5465/AME.2004.12689599

Trompenaars, F. (1993). Riding the waves of culture: understanding cultural diversity in business. London: Nicolas Brealey Publishing.

Trompenaars, F., \& Hampden-Turner, C. (1998). Riding the waves of culture. New York, NY: McGraw Hill.

Tung, R., \& Verbeke, A. (2010). Beyond Hofstede and GLOBE: improving the quality of crosscultural research. Journal of International Business Studies, 41(8), 1259-1274. doi: $10.1057 /$ jibs.2010.41

Uhlenbruck, K. (2004). Developing acquired foreign subsidiaries: the experience of MNEs in transition economies. Journal of International Business Studies, 35(2), 109-123. doi: $10.1057 /$ palgrave.jibs. 8400070

Web of Science. (n.d.). Pesquisa básica. Retrieved from http://apps.webofknowledge.com/WOS_GeneralSearch_input.do?product=WOS\&SID=Q2VSs C8ChkihDbZkvFR\&search_mode=GeneralSearch

Werner, S. (2002). Recent developments in international management research: a review of 20 top management journals. Journal of Management, 28(3), 277-305. doi: 10.1016/S01492063(02)00129-0

Williamson, O. (1975). Markets and hierarchies: analysis and antitrust implications. New York: Free Press.

Williamson, O. (1985). The economic institutions of capitalism: firms, markets, relational contracting. New York: Free Press.

Wit, B. de, \& Meyer, R. (1998). Strategy: process, content, context: an international perspective. London: International Thomson Business.

Yiu, D., \& Makino, S. (2002). The choice between joint venture and wholly owned subsidiary: an institutional perspective. Organization Science, 13(6), 667-683. doi: 10.1287/orsc.13.6.667.494

Young, F. (1985). Multidimensional scaling. In S. Kotz, N. Johnson, \& C. Read (Eds.), Encyclopedia of statistical sciences (Vol. 5, pp. 649-659). Wiley, New York, NY: Wiley.

Zaheer, S. (1995). Overcoming the liability of foreignness. Academy of Management Journal, 38(2), 341-363. doi: $10.2307 / 256683$ 